\title{
“Eye Caught by Another Eye”: Locating Experience in Nadine Gordimer's The Lying Days
}

\author{
Laura Giovannelli \\ University of Pisa, Pisa, Italy
}

\begin{abstract}
In one of the first pages and crucial scenes of The Lying Days (1953), we soon associate the narrating voice with that of a bright, inquisitive child of Scottish descent immersed in the harsh Witwatersrand scenario of a mining estate outskirts in the 1930s, along a path crammed with Jews' concession stores and exotic-looking natives. The unruly little girl is Helen Shaw, the late Nadine Gordimer's fictional double in her still somewhat neglected first novel, a Bildungsroman where the South African writer coming from Springs admirably capitalized on the “camera-eye” perspectives and zooming-in on details which had already informed much of her masterly short fiction. The aim of the present paper is to shed light on Helen's difficult growth towards sociopolitical and ethical awakening—in a country finding itself more and more trapped in the apartheid grip—by pointing out the earliest, embryonic stages of such a progressive knocking down of epistemic barriers. The author will thus focus on "The Mine”, the first and most concise of the three parts making up the novel, and show how Gordimer's acute prose, incisive style, and descriptive strategies prove to be a fitting tool for recording and weighing the experience of an indefatigable observer, a hungry mind in search of erased features, meaningful connections, revealing contexts and subjects.
\end{abstract}

Keywords: functional description, significant detail, segregated communities, apartheid, epistemological growth

\section{Introduction}

Apparently less inclined to comment on her debut novel than address issues relating to her later fiction, especially such masterpieces as The Conservationist, Burger's Daughter and July's People, Nadine Gordimer called nonetheless attention to two main features characterizing The Lying Days. These components are the book's autobiographical background-pivoting on preoccupations which, if inevitably connected with the South African "big theme" of racist policies, the moral agonies of segregation, the attempts to envisage a borderland where whites and blacks might interact, "were still very personal, emotional, very adolescent, as so often happens in first novels" (Walters, 1987, p. 288) —and its peculiarly segmented texture, as the author observed in another interview:

That strictness comes from the discipline of the short story. When I was teaching myself to write, it was the short story I was working on, and I think my first two novels lacked narrative power because I knew how to condense but not how to make the links properly, so that the first novel fell into segments that didn't quite knit. But the getting to the essence of things and the looking for the significant detail come from the discipline of the short story. (Marchant, Kitchen, \& Rubin, 1986, pp. 254-255)

Laura Giovannelli, Ph.D., associate professor, Department of Philology, Literature and Linguistics, University of Pisa. 
If her 1953 novel, which she started writing when she was about 25 (the moment the story draws to a close, Helen Shaw is correspondingly 24), does not excel in conceptual wholeness or skilful plot-construction, it can certainly be praised in relation to what Gordimer defined here and on other occasions as the recording of the "significant detail"1. For one thing, we should naturally keep in mind the discipline gained through the process of short-story writing and the concomitant refinement of the polished, "jewel-cutting style"2 any practised reader of Gordimer is now familiar with. The guiding principles of lucidity, compression, and rhetorical economy, rooted in a seminal frame looking back on E. A. Poe's theoretical assumptions, are almost everywhere to be seen in her short narrative, especially the works dating back to the 1950s and 1960s. On the other hand, there was a quality in the young Nadine's temperament that ought to be mentioned as well: her cleverness at impersonating characters, a proclivity to imitation that she had plenty of opportunities to cultivate, even against her will, due to her mother's influence and involvement in philanthropic initiatives like benefit performances (amateur theatricals) and also to the woman's hyperprotective attitude towards her younger daughter. When nine-year-old Nadine was diagnosed with a heart ailment caused by an enlarged thyroid gland, Hannah (Nan) Myers decided that it would be safer for the little girl to limit physical activity as much as possible, including the dancing lessons her daughter was so keen on. Two years later, Nan engaged a private tutor and took her out of school. During that unwelcome, five-year “quarantine” spent with older people, Nadine devoted herself to omnivorous reading (she regularly borrowed books from the municipal library in Springs), developed literary taste and introspection but also enjoyed observing and mimicking adults, playfully reproducing their linguistic inflexions, manners of expression and often trivial conversations.

Leaving aside the bitter feelings of resentment and loneliness that this odd situation understandably aroused in the budding writer, particularly when she was to realize in later years that hers had not been a serious illness, after all ${ }^{3}$, it is interesting from our point of view to quote again Gordimer's words testifying to an ability to

\footnotetext{
${ }^{1}$ See also the following statement, where the idea is given further strength by the vivid image of the writer's "fresh eye": "It's significant detail that brings any imaginative work alive, whatever the medium. If you can't see things freshly, if you can't build up through significant detail, then I think you fall into cliché, not only in the use of words and phrases, but even in form. That fresh eye is the most valuable thing in the world for any writer. When I look at my early stories, there's a freshness about them, there's a sensuous sensibility that I think you only have when you're very young; after that you go on to analyzing your characters, you go on to narrative strength. But first, you've got to have that fresh eye with which to see the world” (Boyers, Blaise, Diggory, \& Elgrably, 1982, p. 195; italics in the text). Besides the short stories, these remarks may apply equally to several macro-segments of The Lying Days. Indeed, the first part of the novel has a few elements in common with "The Defeated", a story from The Soft Voice of the Serpent (1952) in which a Scots red-haired little girl living on a Mine property disobeys her prejudiced mother and decides to visit the shabby concession store of a Jewish schoolmate.

${ }^{2}$ See Magarey (1974). The most outspoken eulogist of the fine artistry, obsidian-like wit and trait de lumière in Gordimer's (early) style—allegedly at its most polished in her short stories—remains Haugh (1974).

${ }^{3}$ Gordimer dealt with these personal vicissitudes in a fair number of interviews and autobiographical essays. A critic who has most emphasized the link between the author's childhood and relationship to her mother and some essential features in her narrative is Cooke (1985), who, in connection with the motif of the "exploring eye", claimed that in Gordimer's fiction the ways of seeing connoting youth "are determined, above all else, by unusually possessive mothers. ... her novels by themselves reveal her obsessive concern with domineering mothers, the resulting resentment and sense of powerlessness of their children. Gordimer deals with such relationships most concertedly in The Lying Days, Occasion for Loving, and Burger's Daughter, which form an extended Bildungsroman centering on the attempts of daughters to break free of the mother's power and establish lives of their own" (p. 44). This passage from the novel notably testifies to the power of the mother's piercing glance: "I felt, like some secret horror walled up inside me, beating on the walls with cries that nobody but I should ever hear, the panic and anger of being under my mother's eyes. I saw her gaze hardening over me” (Gordimer, 2002, p. 281). Cooke (1985) sounds however quite categorical and pessimistic when contending that "Helen is never quite able to forsake her childhood home. ... The twenty-four-year-old Helen we see about to embark for England at the novel's close remains as much in her mother's thrall as the nine-year-old girl at the novel's outset” (p. 48).
} 
bracket personal suffering — her pathetic resembling a little old woman—and, as it were, make a virtue of necessity. When asked by Peter Marchant about her "wonderful eye" for detail, habits and mannerisms, she reiterated the point of her queerly unique childhood experience as an eavesdropper and jester for grown-ups at tea parties:

As a child, one of the things I enjoyed doing and was encouraged by adults to do for their amusement was to mimic people, and I was really rather good at it. I had a parrot-like ability to mimic an accent or way of speaking, so sometimes when my mother's friends were there, I was mimicking other friends. I now think it was rather an unpleasant thing, but I enjoyed the limelight. Fortunately, these instincts to show off-I was also a dancer and did some amateur acting-all fell away, and whatever this projection of the imagination was and this ability to observe people closely that all writers must have became concentrated on writing quite early on. (Marchant, Kitchen, \& Rubin, 1986, p. 254)

This intriguing hovering between playing by the adults' rules and going about one's aim, or at least trying to carve out a niche for self-expression and censure ${ }^{4}$ —in this case through minute examination and mimicry—can also be seen to inform the protagonist's behaviour in The Lying Days. What follows is one of the most poignant passages taken from "The Mine” (Part One, Sections 1-4) ${ }^{5}$, where Helen Shaw, the first-person narrator, remembers relishing her show in the full glare of an adult audience, consisting of her family friends gathered at a Transvaal tennis club, one of the then innumerable whites-only places:

Soon I was handing round the crumpets, helping with fresh cups of tea. They teased me and talked to me playfully; I blushed when the young men chaffed me in a way that seemed to deepen some secret between them and their girls. But recklessly, I could answer them back, teasing too, I could make them laugh. They said: "Listen to her! —Did you hear that?_-” I stood bridling with pleasure, looking wide out of my eyes in the face of applause.

I went there often on Saturday afternoons after that, accepted as one of them, but with the distinction of being the only child in the party. It was easy to be one of them because I soon knew their jokes as well as they did themselves and, beside my mother, sat a little forward as they did, waiting for each to come out with his famous remark. Then when they rocked and shook their heads at getting just what they had expected, I would jump up and down, clutching at my mother's arm in delight.

I was quite one of them. (Gordimer, 2002, p. 16; italics in the text)

What is also worth noting is how the last, isolated statement, closing both the episode and the first section of "The Mine”, objectifies a kind of climactic seal operating at a typographical, syntactic and semantic level. The phrase encodes in fact Helen's troubled recognition of her racial allegiance, her cultural and ethnic belonging with a privileged, uniform enclave in a strongly polarized society. If not exactly an admission of guilt (relating to connivance and accountability on the whites' part), that assertion carries with it the chilling overtones of a counter-epiphany, since it is made after the child bravely set off on her journey of discovery in the surroundings of the Mine white district, a challenging experience of "culture shock" (Head, 1994, p. 41) and confrontation with a hardly classifiable alterity, which shall be the subject of our commentary in the following pages. Notwithstanding her initial (and, compulsively, future) "tussle to free herself from the effects of her mother's

\footnotetext{
${ }^{4}$ In "A Bolter and the Invincible Summer" (1963), too, Gordimer spoke of her talent for showing off and "a device of the personality that... later became the practical sub-conscious cunning that enabled me to survive and grow in secret while projecting a totally different, camouflage image of myself” (Gordimer, 1989, p. 20).

5 The Lying Days is set in the South Africa of the first half of the twentieth century (1935-1950) and is divided into three parts: “The Mine” (pp. 3-36); “The Sea” (Part Two, Sections 5-19, pp. 39-204); “The City” (Part Three, Sections 20-38, pp. 207-376).
} 
ethnocentric and racist attitudes" (Head, 1994, p. 36), the awareness of being "one of them" should be read here as the protagonist's momentous taking cognizance of the snobbish, fake bourgeois world she was born into. That constricting world mirrored in turn the English-speaking milieu of those "brought up on the soft side of the colour-bar” (Ross, 1965, p. 34), to borrow again Gordimer's words. Such unmasking, right in the aftermath of Helen's temporary leaving home and venturing out to see what lay beyond the complacent British settlers' fences (namely, white lower ranks and the demonized "kaffirs”), can be said to represent a fundamental step towards grasping the internal differences and hybrid texture of the South African reality, with its multiple social constellations.

The complexity and contradictions of that reality—-too often relying on false principles, mutual distrust, racial hatred and "so many lies"6 about hierarchies, the inferiority of the non-whites, the ideas of nation and mother country - will reveal themselves as both a powerful trigger and a smashing obstacle for Helen's Bildung. The narrating (adult) I of the present endeavours to sensibly reconstruct such hard-fought growth through memory and sets about recording it, with all its achievements and failures, only to cut it off in the epilogue-in Section 38, the last one in the text, the speaking voice acquires an almost dismissive, uncommitted tone: "Perhaps this story should end there” (Gordimer, 2002, p. 375)—as though the "new Helen” of young womanhood still needed time (along with a relieving escape to Europe) to interlace the threads of her life and roots. Time to piece together her national and social ties in a broadened, post-Forsterian connection and truly define identity, beliefs, long-term goals.

\section{The Writer and Her Character}

There is thus much more to reckon with, in The Lying Days, than just a "faulty" Bildungsroman falling short of the great tradition's standards and paradigms, such principles being a character's exemplary development from self-referentiality to a purposeful mediation with the world (from fanciful idealism to the acquisition of a suitable role); the figuring out of a synergic symmetry between the individual and society; a quest for identity and integration that unfolds within an overall teleological framework and in concert with the humanistic idea of "education” (not to be confused with compliance or conformism).

This novel rather lays the groundwork for a critical revisiting of a European model which does not appear to

\footnotetext{
${ }^{6}$ See again Boyers, Blaise, Diggory, \& Elgrably (1982), p. 196. The words "lie” and "lying” are obviously key terms in the novel, which takes its title and epigraph from "The Coming of Wisdom with Time” (1909), a four-line poem by W. B. Yeats centring around the painful rite of passage from the joyous illusions of youth to the withering truth of adulthood. Gordimer connects this motif with a specific and at the same time wider context, including both the private sphere of Helen's family, friends and lovers and the public, historical arena of the "big lie" endorsing colonial racism. On the one hand, lying involves the easy enthusiasm of youth as well as the everyday concealments deriving from self-doubt, timidity and the fear of breaking taboos. See for instance the episode in which Helen's mother scolds her because the girl did not soon reveal that she had been living with Paul Clark: "Living with this man and lying, writing letters and lying" (Gordimer, 2002, p. 277). On the other hand, the "lying days" bear the imprint of the harsh truths espoused by the segregationist ethos, with its obnoxious network of duplicities, ranking, dividing and consequent moral or psychic dilemmas for the more sensitive, penetrating minds. An example among scores is offered by the following excerpt, hinting at Paul's "schizoid" splitting between his state-controlled duties as a welfare officer at the Native Affairs Department in Johannesburg and his "illegal" collaboration with the ANC underground forces: "And they became expert at filling in applications for Departmental funds in such a way as to avoid their narrow stringency and stretch their validity to cover expenditure that was officially 'beyond the Department's scope'. 'But I'll wangle it somehow', I have often heard Paul say, telling me of some scheme for which money or facilities were not available. He would narrow his eyes and lift his chin while he thought what lie, what approach, would be best. And though he laughed at his own craftiness that had developed so efficiently out of necessity, there was in his eyes at these times he afterward mocked a concentration of determination, blank, grim, that he did not see” (Gordimer, 2002, p. 267).
} 
fit into the South African context and its tragically distorted sensibilities, neuroses and ongoing warfare. What the "heroic" character needs here is a more penetrating, titanic and subversive energy capable of stretching boundaries so as to shatter deep-seated prejudices, hypocrisy, white mythologies and see beyond the shameful bulwarks of "apartness", that is to say segregationist politics and the institutionalization of apartheid along with "the insidious effects of this ideology on the lives of the people caught in its workings" (Pettersson, 1995, p. 30). In other words, no fulfilling alignment, cultural sharing or Hegelian dialectic between Helen- the Anglophile liberal humanist—and a crudely compartmentalized society affiliated to Afrikaner nationalism is conceivable. The fact that the protagonist may not yet forge her own position in the community is to be explained in the light of both the environment's hostility and the difficulties she encounters in transcending private experience towards public commitment, the taking of a firm (and dangerous) stand on collective issues ${ }^{7}$.

As underscored by Gordimer, her character's preoccupations still clung somehow too tightly to the emotional and politically naïve realm of the (inter)personal ${ }^{8}$. No radical socialist, Helen hopes "to establish meaningful relationships with other races within the existing order of things" (Pettersson, 1995, p. 58; italics in the text). She thereby calls to mind the well-meaning liberal who goes to great pains to deconstruct the colonial frame of mind, repudiates bigotry and petty conservatism and proceeds to champion "decent” behaviour out of a universal belief in tolerance, kindness, equal rights, distributive justice, and the dignity of the individual (such tenets palpably bearing relation to the ethics of multi-racialism in the 1950s South Africa). Piloting her timorous action are personal choices and mildly "boycotting" gestures (tinged with the gnawing pain of guilt and the wish to ease her conscience) which would bypass, but do not effectively challenge, middle-class security or, even less, the system fuelled by Daniel François Malan’s baasskap policy and the Nationalists' creed exalting the "purity” of the white race.

Nevertheless, by progressively moving away from the strait-laced morality and stale provincialism of the Mine, from the narcissistic interlude of infatuation at the sea in Natal and the sham fights, double standards, ineffectual bohemianism of most of her leftist friends in Johannesburg, Helen will finally experience a condition of dawning awareness, as though coming of age through disillusion- "I was twenty-four and my hands were trembling with the strong satisfaction of having accepted disillusion as a beginning rather than an end” (Gordimer, 2002, p. 376)—and via the certainty of her uncertain position in South Africa:

Here there's only the chaos of a disintegration. And where do people like us belong. Not with the whites screaming to hang onto white supremacy. Not with the blacks—-they don't want us. So where? (Gordimer, 2002, p. 359)

Quite a few examples could be provided here of the discernible interlocking between Helen's reflections and

\footnotetext{
${ }^{7}$ In this sense, I find myself only partially agreeing with Newman (1988), who, while recognizing "the subtlety with which Gordimer subverts Eurocentric conventions” (p. 14), investigates The Lying Days from a primarily gender-oriented point of view that risks glossing over (or simply taking for granted) the wider question of ethnic discrimination and white racism. The critic's focus is mainly on the problematic nature of a woman's Bildung in a patriarchal culture, on the inevitably discontinuous and disjointed formation of "a character who is excluded from both the African world and that of the male" (p. 18). In Dimitriu's (2002) adamant tones, one should not be allowed to forget that "The Lying Days may be a Bildungsroman, but Helen is shaped crucially by the special circumstances of the South Africa in which she lives” (p. 40), by the "South African 'typicality'” (p. 42).

8 This is especially made clear through Helen's and her friends' reaction to the first repressive measures backed up by the National Party: "When the impact on individual, personal lives is not immediate and actual, political change does not affect the real happiness or unhappiness of people's lives, though they may protest that it does. ... although they talked gloomily, I did not see in anyone's face the anxious concentration of concern I had seen come so quickly over the sickness of a child, or the haggard foreboding that kept pace with the disintegration of a love affair” (Gordimer, 2002, p. 258).
} 
some of the author's well-known statements about, say, the non-conformist whites embodying a minority rejected by both black militants and white supremacists, or the wearing struggle to sever the apartheid connection to the category of a God-given law, a "natural” and unquestionable order of things, towards the recognition of the humanity and personhood of blacks. At times the writer and her character literally speak in unison. Helen's momentous realization when she says she "had begun to see the natives all around not as furniture, trees, or the casual landmarks of a road through which my life was passing, but as faces; the faces of old men, of girls, of children" (Gordimer, 2002, p. 212) echoes Gordimer's description of the "relationship with the black people among whom we lived as people live in a forest among trees" ("A Bolter and the Invincible Summer”, 1963, in Gordimer, 1989, p. 26). A most telling remark worth quoting is also the one included in the 1977 address at the University of Cape Town "What Being a South African Means to Me", which, alongside the essay "A South African Childhood: Allusions in a Landscape” (1954), hammers home a clutch of essential themes and turning points. As regards the white subject's symbolic rebirth or awakening into a “second consciousness”, Gordimer argued that:

[t]he process is essentially the discovery of the lie. The great South African lie.... What comes of the immediate discovery of the lie is revelation: you cannot feel guilt for being conned. From the time I discovered that what was being concealed by my society was that blacks were people—not mine-boys, not our Lettie, but people, I had the opportunity to become what I think of as a South African. ("What Being a South African Means to Me”, 1977, in Gordimer, 2010, pp. 277-278; my italics)

Both turning the finger of accusation on the devious tendency to take racial divisions at face value, like incontrovertible facts and received views, and wishing to redefine themselves away from over-privilege, the writer and her fictional self are also seen as trying hard to escape the hold of their claustrophobic home. Although the Shaws are not "townspeople" but markedly parochial "mine people", living on the Mine estate of an imaginary South African Atherton —an Anglo-American enclave, as its name suggests, on the tip of the African continent- the unsparing depiction that is offered of the place is not that different from Gordimer's reminiscences of Springs, the small gold-mining town in the Transvaal where she spent her childhood and adolescence and which had developed around the ore reserve itself. Even a cursory comparison between some passages in the novel and the macrotext of the artist's interviews and autobiographical flashbacks gives us insights into a panoply of similarities: the narrow, torpid life of a colonial "tribe", the strip of burned veld, the ravaged landscape of the polluted mine dumps in the East Rand—-man-made hills of yellowish cyanide sand, dark mounds of coal, waste matter from the blasting of underground tunnels—and the government-concession stores

\footnotetext{
${ }^{9}$ Gordimer (“A South African Childhood: Allusions in a Landscape”, 1954, in Gordimer, 2010) thus remarked on the distinction: "The mine people and the townspeople did not by any means constitute a homogeneous population; they remained two well-defined groups. Socially, the mine people undoubtedly had the edge on the people of the town. Their social hierarchy had been set up first, and was the more rigid and powerful. There was a general manager before there was a mayor. ... at each mine the G. M. was not only the leader of society but also the boss, and if one did not revere him as the first, one had to respect him as the second. ... The mine officials and their wives and families lived on 'the property'; that is, the area of ground, sometimes very large, that belonged to each mine and that included, in addition to the shaft heads and the mine offices and the hospital, a sports ground, a swimming pool, a recreation club, and the houses of the officials—all built by the mine. ... At school, I... struck up a long and close friendship with the daughter of an official at one of the oldest and most important mines. So it was that I came to cross the tacit divide between the mines and the town, and to know the habitat, domestic life and protocol of the 'mine people"' (pp. 9-10, 13). George Shaw, Helen's father and perhaps a fictitious embodiment of the mine official mentioned above, is cast as the Assistant Secretary and, afterwards, Secretary at Atherton Proprietary Mines Limited.
} 
on the property, where some shopkeepers generally provided for the miners' needs.

In those days of mounting industrialization and urbanization, black migrant labourers from distant kraals all over southern Africa were commonly employed (and exploited) in the mining districts, and carried with them the vestiges of tribal culture and customs, including a strikingly "native look" (they used to wear earrings, dress in blankets and cover their hair in clay). With hindsight, however, that ostensibly exotic presence must be granted its deep sense of African belonging as opposed to the outlandish (mind)set transplanted by European settlers, whose assumed ontological stability ironically comes down to a position on the periphery:

These men in blankets... brought directly from the tribal situation... when I began to read and think about it I realized that my sense that they were exotic was completely false. It was the other way around. $I$ was the exotic element. (Loercher, 1979, p. 98; italics in the text).

In the novel, such a position is winkingly located in its proper perspective during Helen's mentioned first foray on foot across the veld, along the tar road between Mine and town and then the dust path leading to the Jew stores. It is on this Saturday afternoon in late August that the proud, nice "princess" in kilts and hand-knitted socks, with her shiny red hair tied with a beautiful ribbon, shall half-consciously take on the role of that foreign white element, although still too young (she is probably nine or ten years old) and pampered to read in the "dark brown faces" she comes across anything more than a receptive and unthinking attitude, an existential otherness which may only find expression through the tour-de-force of a paradox steeped in prejudice: "close-eyed, sullen with the defensive sullenness of the defenseless; noisy and merry with the glee of the innocent" (Gordimer, 2002, p. 14). And yet, a few minutes before, Helen's instinct of self-preservation had seemingly alerted her to the weakness and marginality of her own status away from the familiar laager; a status that in this new heterotopic junction is being scaled down from "high" humanity to the helplessness of an insect amid the natives' animality: "I went past feeling very close to the dirty battered pavement, almost as if I were crawling along it like an insect under the noise and the press of natives" (Gordimer, 2002, p. 9).

Clearly under the sway of her emotional turmoil (cocky curiosity eventually turning to fear and revulsion), little Helen epitomizes a presence sweeping in from a different universe and trying to overcome her cosy isolation. She is literally taking a step across the colour bar, perhaps flinging herself into that venture with more boldness than Gordimer ever did at her age, during the shopping expeditions downtown with Nan. Living only a few hundred yards from the gold reserves, Nadine knew about the "dirty stores" on the road linking up their suburb in Springs to the mine, as on

the corner of the stores there was a little café and we white kids used to wander up there to buy sweets and chewing gum. That's perhaps my earliest awareness of black people. ... I used to go up to the stores, and then the mine workers would come down from the compound. Now in those days, they still wore tribal dress. ... of course we white children were always told, "Don’t hang around there. Little girls mustn’t hang around there”, and I grew up with the feeling - nobody explained really why — that because you were a girl and you were white, every black man was in some way a threat to you. (Junction Avenue Theatre Company, 1986, pp. 248-249)

The reader of The Lying Days need not wait long to see Helen hang around there, the bustling "somewhere" counterweighing the inert and sedate "nowhere" of the colonial coterie. In an ironic reversal, it is now up to the settlers' catered-for perimeter - emptied like a house of mirrors - to objectify the terra nullius dimension where, in so much colonial and travel literature, the explorers and pioneers from the West have been shown to exercise 
their masculine dominion, their political, cultural and economic control as the representatives of a "superior" nation. Gordimer's novel dramatically turns such a script of conquest and projection on its head-with the self-absorbed whites guarding their lifeless stronghold—and soon appeals to the motifs of female transgression and the urge to shun any reflected duplications of the self, the obsessive watching of sameness within a stuffy space shell. At the same time, Helen's—a child's—is not going to be an exploitative "act of reclamation" (Innes, 2007, p. 73) of otherness ignited by an imperialist attitude, but an authentic attempt at crossing the border between a condition of paralysis and a life supposedly thriving elsewhere. She, in other words, begins to perceive in filigree that connoting the land is also a stratification of "social, cultural and political spaces" (Nayar, 2010, p. 134) and that it is by coming vis-à-vis such spaces that one can hope to locate experience and sense "rootedness":

In my bedroom I stood before the mirror that was the middle door of the wardrobe, looking at myself. After a long time, steady and unblinking, only the sound of my breath, the face was just a face like other people's faces met in the street. It looked at me a little longer. Suddenly I slammed the door, ran out of the passage which seemed to take up and give out the sound of each of my footsteps as if it were counting them, and through the kitchen which was noting each drip of the tap and the movement of a fly on a potato peeling. I went straight down the garden path and out of the gate into the road. ... "Helen? Where you go-ing-?" A child with her hair in curlers hung over the fence... "Somewhere”, I said, not looking back. (Gordimer, 2002, pp. 5-6, 7)

Besides bearing witness to the character's high power of observation and bent for visualizing —all elements which call to mind young Nadine's "eye for detail” and pitiless anatomizing of her world, as if through the close-ups and tracking shots of a camera - the excerpt above proceeds to bring to the fore Helen's earliest violation of stifling patriarchal (and racist) rules. After her parents left for the tennis courts, she "betrays" them by lying $^{10}$. Instead of doing nothing and staying at home, as promised, she decides in fact to walk on her own as far as the forbidden stores, crowded with the natives hit by social stigma, the allegedly dangerous "boys" any "Miss" must be wary of. What needs stressing here is how in Gordimer's narrative and semiotic imaginary this sort of betrayal of "whitey" codes and bans-“an unwritten law so sternly upheld and generally accepted" (Gordimer, 2002, p. 4) —is part and parcel of a learning process which ought to lead to a decolonization of the mind: what the writer would have called a second birth, a rethinking trajectory that starts taking shape when one leaves the mother's house with a view to breaking away from the crystal dwelling of the white race.

The protagonist will go through a kind of first test, accompanied by the creepy as well as liberating sensation of stripping away the surface assurances of fellow-whites. True, Helen Shaw's cognitive and ethical journey is doomed to stop half-way across the colour line. If going in search of answers, blessed with goodwill and skeptical of preconceived notions, the grown-up child will scarcely achieve maturity in her torn country. As indicated on a proxemical level by her frequent withdrawing on the apartment balcony, during the hardest times of her

\footnotetext{
${ }^{10}$ For a general investigation of the semantic isotopy revolving around the concepts (and issues) of lying, spying, betrayal, hidden knowledge or enforcement of secrecy in Gordimer's novels, see Ettin (1993), whose study "shows how within the space of that African content, but outside it as well, she has explored thematic and literary issues of confidence and betrayal, negotiations of power, tensions of family connections and separations, the urgent compulsions of sexuality, and the narrative strategies of fiction by no means limited to that geopolitical sphere. ... By exposing, by betraying, she has both uncovered the political body's secrets and undermined its pretensions. To do the former, she seems to believe, necessarily means that one will do the latter" (pp. 3-4, 5; italics in the text).
} 
cohabitation with Paul Clark in “The City”"11, she can’t help feeling at a remove, teetering on the brink between the abstract/ideal and actuality, ethnic allegiances and a metaphorical "second birth", a house appendage and a yearned-for erasure of borders. Added to these nerve-racking discrepancies are further traits reflecting poorly on her, such as a now and then credulous or whimsical attitude ${ }^{12}$ and-a sore point that Paul often brings up-her subterranean, ongoing dependence on her mother. The primal scene of a sheltered life tied to "mummy’s strings" does crop up in the text at some crucial moments of Helen's Bildung, instilling doubts about the chances she may actually have to shake off the fetters of her upbringing. On top of that, the protagonist finds no overwhelming inspiration in literary works or in the act of writing itself, thus veering sharply away from her author's personality.

Yet - there is always an adversative clause in Helen's case, since we are faced with an identity-in-transition, a "construction" of full selfhood-character and writer never remain in flat contradiction. When, at the end, Helen is ready to embark on her own for England from Durban, but somehow belittles her forthcoming European stay (together with the primacy of those cultural roots) as if it were a trifling means of escape to be followed by a momentous return to South Africa (like the stage of an epic nostos) ${ }^{13}$, one notes a similarity with Gordimer's stance towards an evanescent mother country abroad and the misleading conviction that the Old Continent should be a synonym for the "real world". When assessing her first trip to England (in 1953, after writing The Lying Days), the author claimed that the journey "brought an understanding of what I was, and helped me to shed the last vestiges of colonialism. ... I realized that 'home' was certainly and exclusively-Africa. It could never be anywhere else” (Hurwitt, 1979 and 1980, pp. 129-130). In the following decades, she would often take up this pivotal motif of Africanness vs. European legacies, the second term of the dyad being more and more perceived as an Anglo-Saxon tie that English-speaking South Africans were to replace with a different, postcolonial type of loyalty, commonality and identification, with other truths and bonds.

It is the sprouting of this dialectic_-paving the way for other modes of thinking beyond prejudiced customs

\footnotetext{
11 The habit of sitting out alone on the balcony can be read as an objective correlative for a fractured consciousness and a psychological suspension between a pre-rational sense of detachment (associated with the sky or the sea) and intellectual apprehension or physicality (the street, the earth): "Sometimes when I came back to the flat earlier than Paul, I would go out onto the little balcony and sit balanced on the wall, my head against the partition which divided our flat from the one next door. Often I had not even troubled to wash or to put my things away; I simply came in, dropped to the bed what I was holding, and wandered out. ... I sat on the edge of the balcony, shut out even from the flat. It was like being in a cage suspended from the invisible ceiling of the sky, and what went on in the sky was at my level. If I did not look down I could forget altogether the existence of the street, and the human perspective which is the perspective of the street, and to which, once your feet are on the ground, you are fixed" (Gordimer, 2002, pp. 286-287). After a few paragraphs, Helen also mentions "the drifting gap between the way I myself believed I was living, and the way the days themselves passed” (Gordimer, 2002, pp. 288-289), while later on her words sound more sombre: "Sitting on the balcony smoking in the sun, I thought, I am like an invalid: between the illness and the cure" (Gordimer, 2002, p. 323; italics in the text).

12 Dimitriu (2002) implicitly alludes to this facet of inconstancy and impulsiveness when recalling "Helen's awareness of wonder... the truth of emotion” pervading "the lunar Helen (the etymological root being 'moon')" (p. 44).

${ }^{13}$ Oddly enough, Cooke (1985) does not read any effectively positive intent in Helen's closing assertion, which in my view sounds instead as particularly resolute: "My mind was working with great practicalness, and I thought to myself: Now it's all right. I'm not practicing any sort of self-deception any longer. And I'm not running away. Whatever it was I was running away from - the risk of love? the guilt of being white? the danger of putting ideals into practice?-I'm not running away from now because I know I'm coming back here" (Gordimer, 2002, p. 376; my italics). In the critic's words, Helen "is leaving for England, she says, but vows to return. The narrative itself makes this claim seem unconvincing; ... Helen protests too much. She ends a solitary figure without a cultural role, running in search of a land her own mother has so often described as 'home'” (Cooke, 1985, p. 60). Chapter 3 in Cooke's study (“Landscapes as Outward Signs in the Early Novels”, pp. 91-130) is however more consonant with the analytical approach that I have adopted in this article.
} 
or repression - that we can read between the lines in Helen's prospect of coming back to South Africa and especially in her comments on the extraneousness of English books and stories (with their set characters and the marvellously green or snowy landscapes) to the southern hemisphere. For her part, Gordimer was to expand further on the question of exoticism, holding that the far-out and unfamiliar features emerging in the texts she read involved in actual fact Europe and America, while the realities at home, a territory at the bottom of the geographical map, were resistant to those grids and deserved to find a voice of their own. In one of the 1994 Charles Eliot Norton Lectures, she again resorted to the metaphor of the scouring eye —of spying, prying into the hidden in quest of startling truths-to account for the writer's "intrusive" and interpretative acumen:

My comprehension of life had been kept so narrow, everything in it painted white... once free of that, I had the writer's healthy selfish instinct to keep open the multiple vision that the fly's eye of the writer had brought me. ("That Other World That Was the World”, in Gordimer, 1995, pp. 130-131).

A patently common denominator with Helen is to be found in the character's lack of interest in European fairy tales, since to her "stories of children living the ordinary domestic adventures of the upper-middle-class English family... were weird and exotic enough" (Gordimer, 2002, p. 11) and she never skimmed through a children's book in which she could detect a feasible portrayal of life. The following passage, taken from one of the peak moments of her expedition outside the Mine estate, is even more telling, as far as the "quick eye" is concerned:

My heart ran fast and trembly, like the heart of a kitten I had once held. I held my buttocks stiffly together as I went along, looking, looking. But I felt my eyes were not quick enough, and darted here and there at once, fluttering over everything, unable to see anything singly and long enough. (Gordimer, 2002, p. 10)

In this reflection resides a metaliterary clue that allows us to approach The Lying Days as, among other things, a training ground for Gordimer's coming to grips with the art and strategies of novel-writing. The character's stare clearly reminds us of the author's "professional gaze" and acts of visual appropriation, originating in the years of her childhood and adolescence through jesting mimicry alongside close observation, and then developing into a more complex attitude related to scrutinizing, eavesdropping, disclosure, and a consciously exegetic framework. As already underscored by Green (1988), what the protagonist "discovers during her brief truancy can also be read as a statement by the novelist of what it means to write fiction in South Africa in the 1950s" (p. 543). The moment the girl arrogates herself the right to look is "analogous to the novelist's seizure of this material, ugly and not previously recorded in print” (p. 544).

\section{The "White Cocoon" and the Outside}

In this paragraph further light will be thrown on "The Mine” and the dynamics of Helen's short flight away from her white-cocoon world and "matchbox life"-a circumscribed, predictable existence-towards a mysterious somewhere that seems to be absolutely worth contemplating in order to establish one's commitment to the land and stop living on a diaphanous surface. Hence the efforts to record, grasp, and piece together that raw material as it meets the protagonist's eye, roving like a TV camera over the surrounding geography and its staggering concoction of traits. The camera-eye paradigm is far from new in connection with Gordimer's early fiction, since it found a first theoretical basis in an essay by Sachs (1959)—who awakened readers to the author's 
striking memory and keen eye for a flood of revealing details-and then in Abrahams's speculations on the writer’s illuminating intelligence and “transparent ego” (1960) as well as through Maclennan’s “vacuum pump” metaphor (1989). Albeit impressed, these critics also felt ill at ease with the clinical coldness of Gordimer's photographic eye and cerebral jigsaws, and hoped for a stylistic and emotional growth in which the panning-shot lens or searchlight of the spectator would be replaced by the X-ray camera of psychological insight and open confrontation with the Colour question.

What might be stressed more is however the hermeneutic component implicit in these primal efforts to fix the essentials of an outdoor environment, with Helen/Nadine endeavouring to draw on the life swarming around her. If her unaccustomed "fresh eye" cannot but follow the threads of metonymic accretion, enumeration without classification and an eclectic yoking of particulars, the effect is all the more powerful on the narratee, who is nudged into deciphering multiethnic place simultaneously with Helen the child. Readers are somehow asked to elbow their way through an expanding canvas, a paratactic array of heterogeneous elements which await systematization in an intelligible syntax and a mature field of vision: an order that, instead of falling within the static categories of amplificatio, redundancy and the ornamental (the classic domain of description as a spatialized ancilla narrationis), should be viewed as explanatory and informative in a broadly Balzacian sense ${ }^{14}$. Gordimer's descriptive strategies in this part of the novel can in sum be defined as dialectically connoted and functional, since their analogical and even imploding texture is meant to convey the perceptions of the experiencing (and bewildered) subject in their step-by-step progression. Here is an excerpt from the ten-page episode concerning the walk to the stores, in which one soon notices the absence of an encompassing, regulating register and cartographic coordinates or taxonomies vs. a potentially endless, rambling catalogue of unfamiliar presences and awkward features just popping up along the way, as it were:

I slowed. But to turn round and go back to the Mine would be to have been nowhere. Lingering in the puffy dust, I made slowly for the stores huddled wall to wall in a line on the veld up ahead.

There were dozens of natives along the path. Some lay on the burned grass, rolled in their blankets, face down, as if they were dead in the sun. Others squatted and stood about shouting... Orange peels and pith were thrown about, and a persistent fly kept settling on my lip. But I went on rather faster and determined, waving my hand impatiently before my face and watching a white man who stood outside one of the stores with his hands on his hips while a shopboy prized open a big packing case. ... Fowls with the quick necks of scavengers darted about between my trembling legs; the smeary windows of the shops were deep and mysterious with jumble that, as I stopped to look, resolved into shirts and shoes and braces and beads, yellow pomade in bottles, mirrors and mauve socks and watch chains, complicated as a mosaic... There were people there, shadowy, strange to me as the black men with the soft red inside their mouths

\footnotetext{
${ }^{14}$ According to Cooke (1985), so “pronounced is Gordimer's skill in creating a sense of place through the accumulation of surface details that her early fiction recalls no novelist so much as Balzac" (pp. 92-93). As regards the element of realist appraisal, Lomberg (1976) also claimed that in "her first novel, The Lying Days, Nadine Gordimer established a pattern which all the other novels were to follow; it has particular applicability to that Bildungsroman, but it signifies a process inherent in her overall vision of life, and is reinforced by her style, which embraces two large principles that, in simple terms, one can call particularising and generalising. The former involves a capacity for microscopic observations of human behaviour, the latter the capacity for discerning general features and principles objectively, and from a distance. The former is allied to a remarkable sensitivity which can capture a nuance of gesture, a shade of feeling; the latter proceeds from an analytic perceptiveness which can succinctly remark the general features which characterise an individual, or descry the larger principles manifested in specific instances” (p. 32). I obviously agree with Lomberg when he adds that the seeds of Helen's development "are contained in the first chapter of the novel; and, significantly, the first incident in the novel is an act of rebellion on Helen's part. ... If the walk to the tennis courts may be seen to prefigure Helen's growth to independence of attitude-a determination to look at the world herself and make her own judgements about it — the walk also reveals her extraordinary sensitivity to the world around her" (p. 34).
} 
showing as they opened in the concentration of spending money. There was even a woman, in a flowered alpaca apron, coming out to throw something into the pavement crowd. (Gordimer, 2002, pp. 9-10)

Lying behind what Barthes (1986) called the "reality effect" or "referential illusion” (p. 148) linked to the use of descriptive details and notations in much realistic literature is Gordimer's carrying out of an experiment in extra-textual witnessing and truth-telling, a "veritable tour de force" (Clingman, 1986, p. 31): no simplistically conceived transposition of reality or "verbal mirror" of experience, but a virtually faithful representation enacted in accordance with what she believed to be a manageable correspondence between linguistic signs and the worldly, lexis and entities or phenomena. If lacking in cohesion and elaborate transitions, Helen's empirical and descriptive testimony proceeds to mark a field of environmental encodings, social significances, and constructions: her survey is a discontinuous and sometimes chaotic mapping that calls for careful arrangement and sets the agenda for a deeper, future understanding. The telling fact, the layering of "significant details" are nonetheless hard to miss-let's just think of the panning-shot description quoted above, with the natives' blankets, the fly and putrescent oranges, the synecdochic "jumble", the red inside the black men's mouths—so that the worldview that is pushed into being can be said to waver between the poles of mimetic transparency and semantic opacity, in line with the idea of a gradual structuring of experience across the colour bar and its segregated imaginary.

No need for such a structuring in the regimented circle of the English-owned Mine estate in Atherton, pervaded by a sense of atrophy and obsessively regulated by codes, race and class distinctions, inescapable social rituals $^{15}$. This is the environment of which Gordimer’s “candid camera” and its “marvelous quick shots” (Haugh, 1974, p. 94) provide the most unvarnished, merciless depiction: from the memorable incipit—where Helen's defiance of her parents and the Saturday "tennis party" already offers evidence of her wish to transcend family strictures and complacency ${ }^{16}$ — to the paragraphs following the crossing of the veld strip towards the stores. In the second half of "The Mine" we take in fact a closer look at the apathetic life of the white community and its cocoon-like habits, timed to the daily round of men's duties and the drawing-room chattering, charity work, household chores of the wives (unfailingly helped by native girls). All this is laced together with their leisure activities, cake sales, dances and decent little treats, like the tasting of scones and tea laid on an embroidered cloth, a ritual which ironically closes and trivializes the episode of a strike organized by 200 black miners, demonstrating in front of the Compound Manager's house because of an unwelcome change in their diet (the

\footnotetext{
${ }^{15}$ As Clingman (1986) lucidly observes, an "extraordinarily strict hierarchy governs the Mine estate on which the young Helen grows up; the novel details its written and unwritten codes. For the men, the pyramidal chain of command on the Mine is repeated in every aspect of their social and economic lives, down to the respective sizes of the houses to which they are assigned, and their access to private use of black workers as 'garden boys' to care for their lawns. For the women a ritualized and formalized pattern governs the cycle of their entire existence; after school they are expected to attend a secretarial course, work for six months, get married (preferably to Mine men), have children, go to tea parties and preside over the same pattern in the younger generation” (p. 28).

${ }^{16}$ See especially how her relationship with Jess Shaw, her mother, is vividly conjured up through a studiedly selected range of physical and behavioural focalizations related to a worn-out bourgeois script: "My mother was pinning her hair ready for her tennis cap, looking straight back at herself in the mirror. Up-down, went her shoulders. 'I don't know. She's not pleased with anything I suggest'. But her indifference was not real. She followed me out into the garden where I stood in the warm still winter afternoon. 'Now what are you going to do? Do you want to come with Mommy and Daddy and bring your book?' New powder showed white where the sun shone full on her nose and chin; ... In a sense of power, I did not answer; my mother's face waited, as if I had spoken and she had not quite heard. 'Eh? What are you going to do?' 'Nothing', I said, richly sullen. I saw the bedroom windows jerked in by an unseen hand; my father was ready, too. They were both waiting, their afternoon dependent upon me” (Gordimer, 2002, p. 3).
} 
strikers are seen as easily subsiding when granted their Sunday ration of beer).

While delving into this rarefied atmosphere, infused with lavender-water and Eau-de-Cologne perfumes, populated by "white figures” with "pink faces” (Gordimer, 2002, p. 15) arranged as though in a painting and living in houses of dark brick with similar windows and low roofs, the narrator/director generally assembles her shots sequentially and with the gem-polisher's panache, in a meticulous order that mirrors the only too familiar hierarchy of that small world. Everything changes when Helen projects herself from the orbit of this controlling vision into the ramified horizons of an abrasively novel and baffling landscape, that is to say when her metaphorical camera is pointed towards the "outside". What still needs highlighting in this connection is a focal incident characterizing the little girl's Saturday excursion (she will go on other outings with her parents, but none of them will have the same impact as that earliest, solitary venture). This event should be considered as the climax of the textual unity concerning the stores, and perhaps of the whole first part of The Lying Days, for it immortalizes in a nutshell a moment of bare, dislocating confrontation between the white subject and otherness, in a way that is both epiphanically connoted and scoffingly recalcitrant.

In her painful attempt at stringing together a heap of local particulars, Helen frequently resorts to visual memory - as previously evidenced — but also appeals to hearing and smell, to a "lavish use of synesthesia" (Cooke, 1985, p. 53) that strengthens her narrativized description by means of additional references to music and shouting, the nasty smells of burned mealies, rotting oranges, sweat, urine and animal entrails. Now definitely a long way off the well-kept, white family shaw —her ethnic "small wood", in the literal sense of the word—-the protagonist explicitly reminds the (European) reader of the little heroes in the only transmigrated fairy tale capable of piquing her curiosity, namely Hansel and Gretel. Like the two siblings, "anonymous, nobody's children, in the woods" attracted to "the gingerbread house" (Gordimer, 2002, p. 11), little Nell of The Lying Days will fall under the spell of the old anthropophagous witch, whose strangely edible cottage is here africanized and substituted by a native medicine shop (is there perhaps a dig at poor little Nell in Dickens's The Old Curiosity Shop, too?).

Watching the exotic knick-knack through the window, Helen starts to feed her "hungry eyes" and take in the spectacle of "dusty lions' tails, ... piles of wizened seeds, ... flaking gray roots and strange teeth" (Gordimer, 2002, p. 11), until the targets of her voyeurism seem to become animated and thereby dangerous, voracious in their turn. After comparing that hodgepodge of oddities to the winking eye of a crocodile looking like an inoffensive log, she is actually faced with a living being, the master of camouflage par excellence:

I pressed nearer the window and made a spy hole with my hand against the rheumy glass to see in better, and as I did so my eye was caught by another eye. Something was alive in the window: a chameleon, crouched motionless... One eye in the wrinkled socket looked ahead, the other swiveled back fixed on me. Ah-h! I cried, ... a long thin tongue like one of those rude streamers you blow out in people's faces at Christmas shot unrolled and curled back again with a fly coiled within it. The thin mouth was closed, a rim of pale green. Both eyes turned backward looking at me. (Gordimer, 2002, pp. 12-13)

If the doomed witch in Hansel and Gretel had very weak eyes, this creature is both a personification of adaptability and sensitive blending into its surroundings—precisely what the human protagonist still lacks—and a symbol of awareness, given its legendary eyesight, endowed with a 360-degree arc of vision and orienting itself through daily and ultraviolet light. With its rotating and separately mobile eyes, the chameleon can 
simultaneously focus ahead on its environment and back towards the fair-skinned human stranger, whose stare is thus patently outfought. The fly coiled within the long sticky tongue also comically revives the spectre of cannibalism, since Helen had previously felt like an insect crawling under the press of natives. As though sensing and translating these fears into a performing act, and determined to check the spectator's reactions to the show, the animal behind the glass — a synecdoche for a flickering and polychromatic dimension unfolding in the veld — does away with its victim and then turns both eyes on a level with the child.

The climactic episode of the chameleon's brazen, returning look stands as a cameo, if not a mise en abyme, of Helen's first experience off the white cocoon's beaten track: she takes quite a long leap, makes the most of her power of observation, but must also come to terms with the limits of her apprehension and the fact that this scattered social geography is anything but blind or pliable, and does not lend itself to a smooth reconstruction into a whole. If temporarily overwhelmed - the sexually tinged image of a urinating Mine boy, seen from behind, will soon propel her to retrace her steps to the tennis-club shelter and parental security-she has at least perceived the living and (re)acting presence of the Other. She gets home safely, as Hansel and Gretel did, but with no glittering trophy.

\section{Conclusion}

Looking and being looked at: this is the semantic circuitry that often underpins the narrative development of The Lying Days, throughout a milling around of surface impressions and a gradually clearer focusing, within moments of cognitive assimilation and disclosure of the suppressed. Seeing and watching, and especially the "electric contact” created when an eye is "caught by another eye”, can be considered here as primary modes of perceptual grasp, achieving (self-)awareness and locating experience. This is of course true for Helen the child, but keeps on playing a relevant role in the next stages of her growth, too, until the very end of the story, when she is made to witness the killing of a rioter by the police in a black township, during the 1950 May Day strike. Sitting in the car with Laurie, while searching for Paul, who might be in danger, she unwillingly becomes the spectator of that shockingly violent death:

There were more shots, shots and their echo, clearing a split second of silence in the space of the retort. The man with the stones looked up with a movement of surprise, as if someone had tapped him on the shoulder. Then he fell, the stones spilling before him. I knew I had never seen anyone fall like that before. ... I was pulled away with my eyes still fixed on the only thing that I saw: the man lying in the road. (Gordimer, 2002, p. 333)

At the same time, one cannot deny that this momentously dramatic event represents a psychological breaking-point for the protagonist, who, talking later about this to Joel Aaron-her dear Jewish friend and a different kind of authorial projection, giving voice to a more comprehensive moral conscience and a dialectical frame of mind, capable of seeing through people-will regretfully complain that it "happened around me, not to me. Even the death of a man; behind a wall of glass” (Gordimer, 2002, p. 359).

The shop window materializing the distance between the chameleon and the child, the window of the immobilized car (a protective shell in itself) and the metaphorical wall of glass that still keeps Helen the woman severed from her South African connections: these are again significant, visually rendered details through which Gordimer lays bare her protagonist's failures. Discouragement and unbreakable barriers are however one side of the coin. The other is epitomized by the inalienable gaze ready to scrutinize and decipher, until it possibly reaches 
the hermeneutic stage of "spelling... out feature by feature" (Gordimer, 2002, p. 215), the way Helen does with the face of Paul, the only man she has deeply fallen in love with. As Clingman (1986) puts it, if close observation is “a precondition of Gordimer's historical consciousness” (p. 8), then The Lying Days notably manages to take in "a veritable wealth of social observation of the world with which it engages, and this is also the first level at which it tells a 'history from the inside"” (p. 27).

\section{References}

Abrahams, L. (1960). Nadine Gordimer: The transparent ego. In R. Smith (Ed.), Critical essays on Nadine Gordimer (pp. 26-30). Boston: G. K. Hall \& Co.

Barthes, R. (1986). The reality effect, 1968. In The rustle of language (pp. 141-148) (R. Howard Trans.). Oxford: Blackwell.

Boyers, R., Blaise, C., Diggory, T., \& Elgrably, J. (1982). A conversation with Nadine Gordimer. In N. Topping Bazin, \& M. Dallman Seymour (Eds.), Conversations with Nadine Gordimer (pp. 185-214). Jackson and London: University Press of Mississippi.

Clingman, S. (1986). The novels of Nadine Gordimer: History from the inside. London, Boston and Sydney: Allen \& Unwin.

Cooke, J. (1985). The novels of Nadine Gordimer: Private lives/public landscapes. Baton Rouge and London: Louisiana State University Press.

Dimitriu, I. (2002). The civil imaginary in Gordimer's first novels. English in Africa, 29(1), 27-54.

Ettin, A. V. (1993). Betrayals of the body politic: The literary commitments of Nadine Gordimer. Charlottesville and London: University Press of Virginia.

Gordimer, N. (1989). The essential gesture: Writing, politics and places (S. Clingman Ed. and intr.). Harmondsworth: Penguin.

Gordimer, N. (1995). Writing and being: The Charles Eliot Norton Lectures, 1994. Cambridge, Massachusetts and London: Harvard University Press.

Gordimer, N. (2002). The lying days. London: Bloomsbury.

Gordimer, N. (2010). Telling times: Writing and living, 1954-2008. London: Bloomsbury.

Green, R. (1988). From The lying days to July's people: The novels of Nadine Gordimer. Journal of Modern Literature, 14(4), 543-563.

Haugh, R. F. (1974). Nadine Gordimer. New York: Twayne Publishers.

Head, D. (1994). Nadine Gordimer. Cambridge: Cambridge University Press.

Hurwitt, J. (1979 and 1980). The art of fiction LXXVII: Nadine Gordimer. In N. Topping Bazin, \& M. Dallman Seymour (Eds.), Conversations with Nadine Gordimer (pp. 127-160). Jackson and London: University Press of Mississippi.

Innes, C. L. (2007). The Cambridge introduction to postcolonial literatures in English. Cambridge: Cambridge University Press.

Junction Avenue Theatre Company. (1986). Nadine Gordimer. In N. Topping Bazin, \& M. Dallman Seymour (Eds.), Conversations with Nadine Gordimer (pp. 247-252). Jackson and London: University Press of Mississippi.

Loercher, D. (1979). South Africa’s Nadine Gordimer: Novelist with a conscience. In N. Topping Bazin, \& M. Dallman Seymour (Eds.), Conversations with Nadine Gordimer (pp. 96-100). Jackson and London: University Press of Mississippi.

Lomberg, A. (1976). Withering into the truth: The romantic realism of Nadine Gordimer. In R. Smith (Ed.), Critical essays on Nadine Gordimer (pp. 31-45). Boston: G. K. Hall \& Co.

Maclennan, D. (1989). The vacuum pump: The fiction of Nadine Gordimer. Upstream, 7(1), 30-33.

Magarey, K. (1974). Cutting the jewel: Facets of art in Nadine Gordimer's short stories. In R. Smith (Ed.), Critical essays on Nadine Gordimer (pp. 45-74). Boston: G. K. Hall \& Co.

Marchant, P., Kitchen, J., \& Rubin, S. S. (1986). A voice from a troubled land: A conversation with Nadine Gordimer. In N. Topping Bazin, \& M. Dallman Seymour (Eds.), Conversations with Nadine Gordimer (pp. 253-263). Jackson and London: University Press of Mississippi.

Nayar, P. K. (2010). Postcolonialism: A guide for the perplexed. London and New York: Continuum.

Newman, J. (1988). Nadine Gordimer. London and New York: Routledge.

Pettersson, R. (1995). Nadine Gordimer's one story of a state apart. Stockholm: Almqvist \& Wiksell.

Ross, A. (1965). Nadine Gordimer: A writer in South Africa. In N. Topping Bazin, \& M. Dallman Seymour (Eds.), Conversations with Nadine Gordimer (pp. 33-42). Jackson and London: University Press of Mississippi.

Sachs, B. (1959). Nadine Gordimer: Writer with the eye of a camera. In South African personalities and places (pp. 83-89). Johannesburg: Kayor Publishers. 
Smith, R. (1990). Critical essays on Nadine Gordimer. Boston: G. K. Hall \& Co.

Topping Bazin, N., \& Dallman Seymour, M. (1990). Conversations with Nadine Gordimer. Jackson and London: University Press of Mississippi.

Walters, M. (1987). Writers in conversation: Nadine Gordimer. In N. Topping Bazin, \& M. Dallman Seymour (Eds.), Conversations with Nadine Gordimer (pp. 285-298). Jackson and London: University Press of Mississippi. 